Article

\title{
Technological Approaches to Sustainable Agriculture at a Crossroads: An Agroecological Perspective
}

\author{
Miguel A. Altieri ${ }^{1, *}$, Clara I. Nicholls ${ }^{2}$ and Rene Montalba ${ }^{3}$ \\ 1 Department of Environmental Science, Policy and Management (ESPM), University of California, \\ Berkeley, CA 94720, USA \\ 2 International and Area Studies, University of California, Berkeley, CA 94720, USA; nicholls@berkeley.edu \\ 3 Departamento de Ciencias Agronomicas y Recursos Naturales, Universidad de la Frontera, \\ Francisco Salazar, 01145 Temuco, Chile; rene.montalba@ufrontera.cl \\ * Correspondence: agroeco3@berkeley.edu
}

Academic Editors: Manuel González de Molina and Gloria Guzman

Received: 24 November 2016; Accepted: 23 February 2017; Published: 27 February 2017

\begin{abstract}
Most efforts to improve agricultural production remain focused on practices driven by an intensification agenda and not by an agroecological one. Agroecology transcends the reformist notion of organic agriculture and sustainable intensification proponents who contend that changes can be achieved within the dominant agroindustrial system with minor adjustments or "greening" of the current neoliberal agricultural model. In the technological realm, merely modifying practices to reduce input use is a step in the right direction but does not necessarily lead to the redesign of a more self sufficient and autonomous farming system. A true agroecological technological conversion calls into question monoculture and the dependency on external inputs. Traditional farming systems provide models that promote biodiversity, thrive without agrochemicals, and sustain year-round yields. Conversion of conventional agriculture also requires major social and political changes which are beyond the scope of this paper.
\end{abstract}

Keywords: agroecology; organic agriculture; conversion; transition; Latin America; California

\section{Introduction}

In Latin America, agroecology is not only a scientific-technological project, but a political one. Agroecology is viewed as an applied science embedded in a social context, problematizing capitalist relations of production and allying itself with agrarian social movements [1]. Most agroecologists have embraced the critiques of top down rural development and recognized and supported the peasantry in their new role in the resistance against the advancement of the corporate food system, industrial agriculture and neoliberal policies [2].

It is precisely this political dimension of agroecology that is problematic for the application and spread of agroecology in the USA, Europe, Australia, Japan and other regions in the industrialized world. Challenging the root causes of the environmental and social crisis of industrial agriculture implies challenging capitalism. Given such challenge, a naive notion prevails that socio-ecological changes can be achieved within the current food system with just a little tweaking and "slight greening" of the industrial agricultural model [3]. Using a variety of names (sustainable intensification, climate smart agriculture, diversified farming systems, adaptive management, etc.), a lukewarm definition of agroecology has emerged, regarding it essentially as a set of additional tools to fix the problems of industrial food production. In other words, many researchers see agroecology as a way to make conventional agriculture a little bit more sustainable, without challenging underlying relations of power, nor the structure of large-scale monocultures [4]. No doubt, agroecology is now at a crossroads, facing a major struggle over its possible cooptation by the mainstream and to be further subordinated 
to conventional agriculture by revisionist academic projects that erase its history, stripping it of its political content and goals [5].

The technological paradigm espoused by such "a-political" conception of agroecology carries the same shortfalls. Defining agroecology solely as a science and practice of applying ecological principles to the design and management of sustainable farms [6] opens the door to a variety of competing narratives, each suggesting different pathways to supposedly reach healthier agricultural futures. Hallmarks of what are termed agroecological farming practices include integrated pest management, organic farming, conservation agriculture, regenerative agriculture, sustainable intensification, etc., all approaches based on practices that imply only minor adjustments to the industrial farming model.

In this paper, we argue that what is required, is to rescue agroecology from the confines of academia and non-governmental organizations, into the political arena of progressive social movements that embrace agroecology as a pillar of food sovereignty, local autonomy, and community control of land, water and agrobiodiversity. Promoting an agriculture based on practices that increase the efficiency of input use or that substitute biologically based inputs for agrochemicals, but that do not challenge the monoculture structure, do not have the potential to lead to a more autonomous redesign of sovereign agricultural systems. A true agroecological technological conversion calls into question monoculture and the dependency on external inputs. This conversion also implies socio-political dimensions that are beyond the scope of this paper.

\section{Agroecology, Organic Farming and Sustainable Intensification}

There are many manifestations of alternative agriculture: biodynamic agriculture, organic farming, permaculture, natural farming and others. All these methods promote a diverse range of alternative practices designed to reduce dependence on synthetic chemical pesticides, fertilizers, and antibiotics, and cut production costs, which in turn diminish adverse environmental consequences of modern agricultural production [7]. One of these systems is organic agriculture which is practiced in almost all countries of the world, and its share of agricultural land and farms is growing, reaching a certified area of more than 30 million hectares globally. Organic farming is a production system that sustains agricultural productivity by avoiding or largely excluding synthetic fertilizers and pesticides. Instead organic farmers rely heavily on the use of crop rotations, cover cropping and green manuring, crop residues, animal manures, legumes, off-farm organic wastes, mechanical cultivation, mineral-bearing rocks, and aspects of biological pest control to maintain soil productivity and tilth, to supply plant nutrients, and to control insect pests, weeds, and diseases [8].

Pushed by market forces that privilege specialization, many organic farmers have no choice but to replace practices such as rotations, cover cropping, etc. with a set of energy and capital intensive organic "technology packages" and input substitutions, making their operations dependent and intensive [9]. Conversion has been conceptualized as a transitional process with three marked: (1) Increased efficiency of input use through integrated pest management or integrated soil fertility management; (2) Input substitution or substitution of environmentally benign inputs; and (3) System redesign-diversification with an optimal crop/animal diversified assemblage, which encourages synergisms so that the agroecosystem may sponsor its own function [10]. Many of the practices that are currently being promoted as sustainable fall in categories 1 and 2. Both of these stages reduce environmental impacts as they decrease agrochemical input use. Solely increasing the efficiency of input use or substituting biologically based inputs for agrochemicals, but leave the monoculture intact, do little to move farmers toward the productive redesign of agricultural systems.

Many of the "alternative inputs" used in organic farming have become commodified, therefore farmers continue to be dependent on input suppliers. In California, many organic farmers cultivating grapes and strawberries apply between 12 and 18 different types of biological inputs per season enhancing production costs. Many products used for one purpose affect other aspects of the system. Sulfur used to control foliar diseases of grapes, can also wipe out populations of Anagrus parasitic wasps, key regulators of leafhopper pests. Thus farmers become trapped in an "organic treadmill" [11]. 
Many agroecologists argue that improvements in efficiency of input use and input substitution must give way to farming system redesign based on a new set of ecological relationships, which entails basing conversion on principles of agroecology [12]. The core principles of agroecology include recycling nutrients and energy on the farm, rather than introducing external inputs; enhancing soil organic matter and soil biological activity; diversifying plant species and genetic resources in agroecosystems over time and space; integrating crops and livestock and optimizing interactions and productivity of the total farming system, rather than the yields of individual species [13,14].

Recently FAO [15] along with other international organizations (i.e., CGIAR) have embraced a version of agreocology, regarded as an option that can be practiced along with other approaches such as transgenic crops, conservation farming, microdosing of fertilizers and herbicides, and integrated pest management. They propose adjusting the ecological inefficiencies of industrial agriculture through "sustainable intensification", e.g., by increasing efficiency of water and fertilizer use, and confronting climate change by deploying "climate-smart" genetic varieties. Of course this vision renders the term agroecology meaningless, like sustainable agriculture, a concept devoid of meaning, and divorced from the reality of farmers, the politics of food and of the environment. In fact, these superficial technical adjustments are ideologically buttressed by intellectual projects to reframe and redefine agroecology by stripping it of its political and social content and promote the wrong notion that agroecological methods can co-exist alongside the aggressive expansion of industrial agriculture, transgenic crops and agrofuels [16]. Agroecology does not need to be combined with other approaches. Without the need of hybrids and external agrochemical inputs, it has consistently proven capable of sustainably increasing productivity and has far greater potential for fighting hunger, particularly during economic and climatically uncertain times, which in many areas are becoming the norm.

\section{Traditional Agriculture as Sustainability and Resiliency Models}

In the current realm of commercial agriculture, it is difficult to find agricultural systems that promote biodiversity, thrive without agrochemicals, and sustain year-round yields. For this reason, in their search for new and promising models, agroecologists have turned their attention to the study of traditional agriculture. Such complex farming systems, adapted to local conditions, have helped small farmers to sustainably manage harsh environments and to meet their subsistence needs, without depending on mechanization, chemical fertilizers, pesticides or other technologies of modern agricultural science [17]. Guided by an intricate knowledge of nature, traditional farmers have nurtured biologically and genetically diverse smallholder farms with a robustness and a built-in resilience necessary to adjust to rapidly changing climates, pests, and diseases, and more recently to globalization, technological penetration, and other modern trends [18].

A salient feature of traditional farming systems is its high level of biodiversity deployed in the form of polycultures, agroforestry and other complex farming systems, in which the ecological interactions among plant, animal and soil components promote key processes such as nutrient cycling, pest regulation and productivity. Guided by an acute observation of nature, many traditional farmers have intuitively mimicked the structure of natural systems with their cropping arrangements [19]. Examples of such bio mimicry abound and below we describe two striking examples from which principles can be derived to design modern agroecosystems.

\subsection{The Rice-Fish-Duck Systems in China}

The main species present in many Chinese traditional rice paddies include fish, ducks, weeds, plankton, photosynthetic bacteria, aquatic insects, benthos, rice pests, water mice, water snakes, birds, and other soil and water microbes. In addition, farmers plant up to ten different species of indigenous vegetables in the field borders of the terrace fields, where also at least 62 forest species thrive; 21 of these used as food and 53 for medicinal and herbal purposes [20]. These rice based farming systems support a variety of beneficial interactions: the various species of fish (Tilapia nilotica and Cyprinus carpio) consume insect pests (mainly leaf hoppers and leaf rollers) that attack the rice plant as well as weeds 
that choke rice plants and rice leaves infected by sheath blight disease thus reducing the need for pesticides. These systems exhibit a lower incidence of insect pests and plant diseases when compared to monoculture rice farming [21]. Further, the fish oxygenate the water and move the nutrients thereby benefiting the rice. Azolla species proliferate fixing nitrogen $(243-402 \mathrm{~kg} / \mathrm{ha})$ some of which $(17 \%-29 \%)$ is used by the rice [22]. The ducks consume the Azolla before it covers the whole surface and triggers eutrophication, in addition to consuming snails and weeds. By consuming biomass, the fish and ducks reduce the methane emissions otherwise produced by decomposing vegetation by up to 30 percent, as compared to conventional farming. Clearly, the complex and diverse food webs of microbes, insects, predators and associated crops plants promote a number of ecological as well social and economic services, beneficial to the local rural communities (Figure 1).

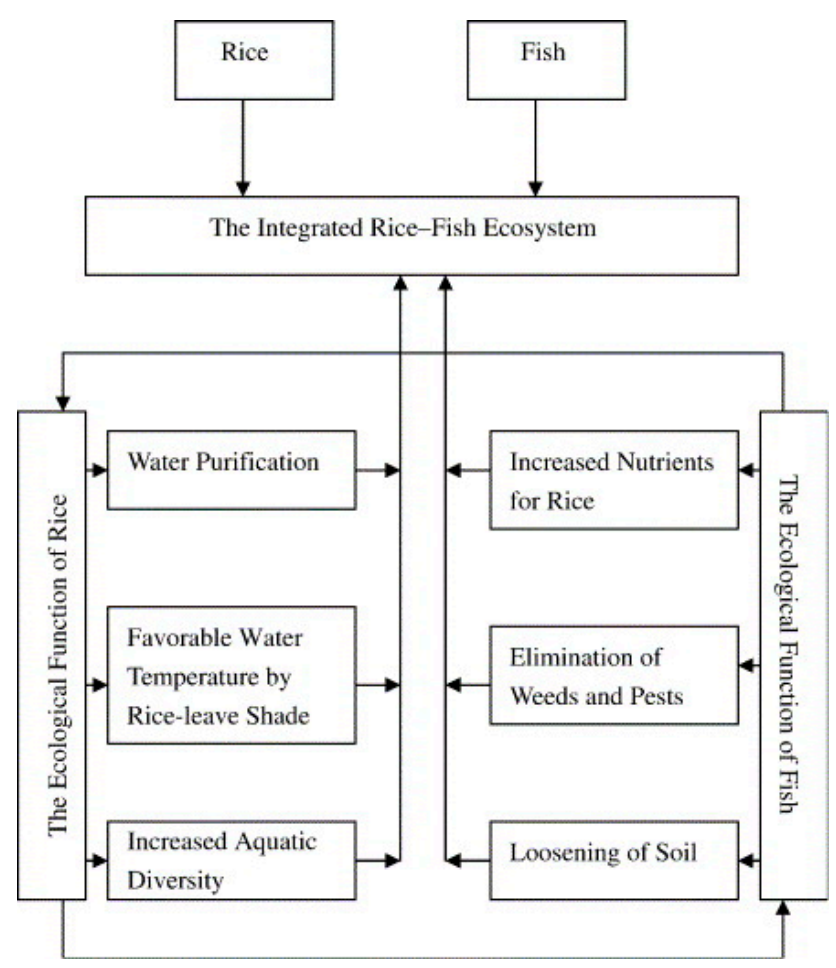

Figure 1. Interactions among different components in Chinese rice-fish-duck agricultural systems [20].

\subsection{The Milpa}

Intercropping is a form a bio mimicry which is widely practiced in Latin America, Asia, and Africa by smallholders as a means of increasing crop production per unit land area, with limited capital investment and minimal risk of total crop failure [23]. In these traditional multiple cropping systems, productivity in terms of harvestable products per unit area can range from $20 \%$ to $60 \%$ higher than under sole cropping with the same level of management [24]. The mechanisms that result in higher productivity in diverse agroecosystems are embedded in the process of facilitation. Facilitation occurs when one crop modifies the environment in a way that benefits a second crop, for example by lowering the population of a critical herbivore, or by releasing nutrients that can be taken up by the second crop [25]. Pest and pathogen incidence is generally lower in intercrops due to associational resistance effects [26] and higher total resource use efficiency results when growing together crops with different root systems and leaf morphologies. Usually a combination of two contrasting species, usually a legume and a cereal, leads to greater overall biological productivity than each species grown separately because the mixture can use resources more effectively than separate monocultures [27]. Intercropping is an effective agroecological strategy of introducing more biodiversity into agroecosystems and increased crop diversity usually increases the number of ecosystem services provided. Higher species 
richness of planned and associated biodiversity improves nutrient cycling and soil fertility, limit nutrient leaching losses, reduces the negative impacts of pests, diseases and weeds and enhances overall resilience of the cropping system (Figure 2) [28].

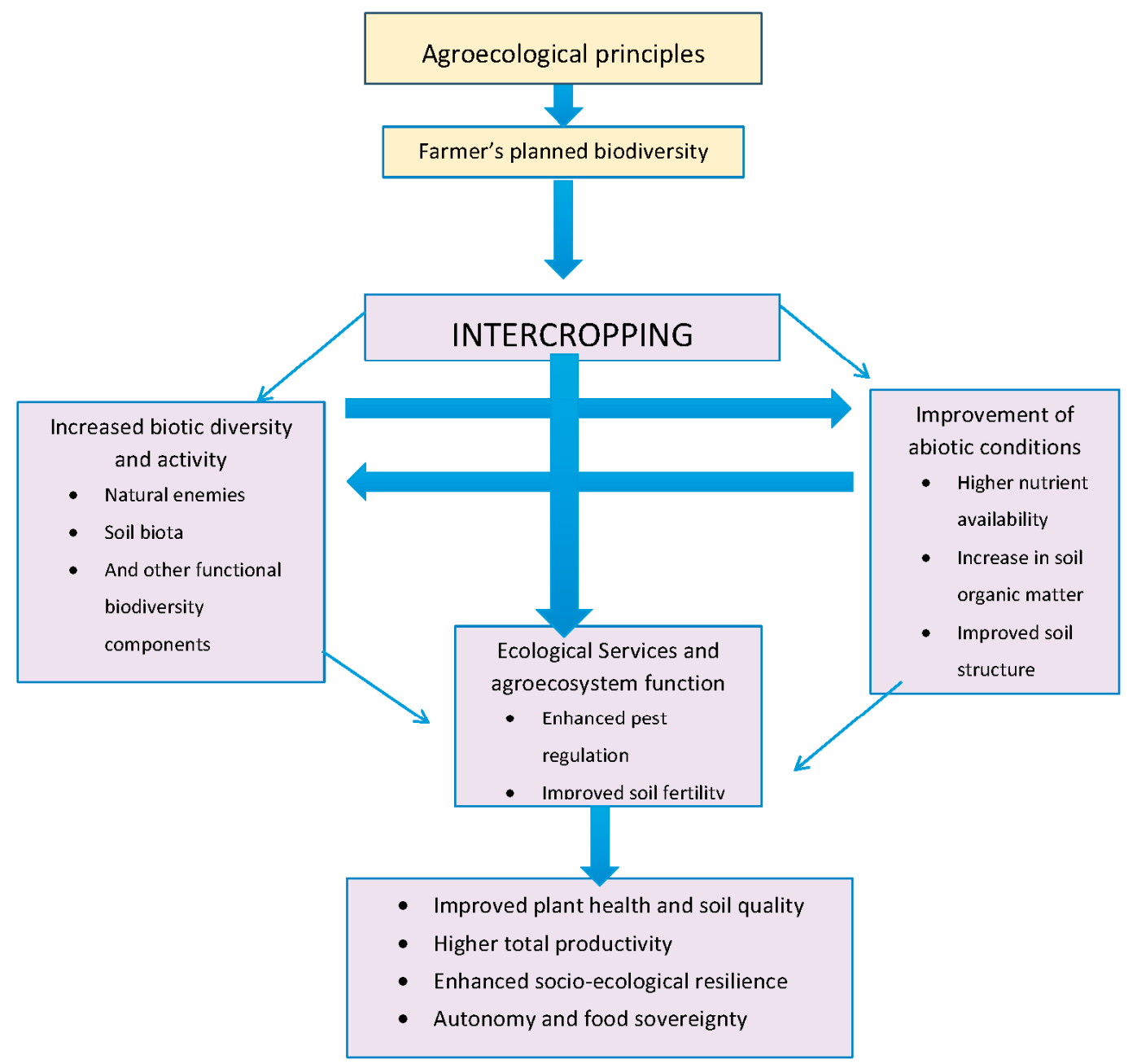

Figure 2. Socio-Ecological outcomes from intrecropping systems designed based on agroecological principles.

Among the most prevalent intercropping systems is the "milpa", a polyculture originated and still practiced in Mexico and the rest of Mesoamerica. In this system maize, common beans and squash are typically grown in association, sometimes along with tomatoes, multiple varieties of chilies and semi-domesticated herbs (quelites). In this system, beans fix nitrogen which benefit maize, but also harbor beneficial insects that control maize pests. Squash plants suppress weeds and protect against erosion by quickly covering the soil. Maize provides support to climbing beans and shade for beans creating a microclimate unfavorable to certain insect pests while also preserving moisture. In addition, maize forms a physical barrier against certain diseases by blocking the dissemination of spores [23]. All these interactions favor productivity leading to over yielding; the crop mixture yields more than any monoculture of the component species despite their low use of chemical inputs. Most studies reveal land equivalent ratios (LER) values for maize/bean polycultures higher than 1.5 [24]. In Mexico, 1.73 ha of land has to be planted with monoculture maize to produce as much food as one hectare planted with the traditional milpa (mixture of maize, beans and squash). 
Most milpa farmers destine maize cultivation to obtain grain for human consumption and seeds for the following agricultural cycle, as well as straw for direct consumption of households' animals. Our studies in Tlaxcala showed that a typical milpa parcel produces on average $1200 \mathrm{~kg}$ of maize grain per hectare [29]. Daily consumption of maize is on average $3 \mathrm{~kg}$ per household, thus maize production (without accounting for the yields of beans, squash and other crops and quelites (which amount to an additional total edible biomass of approximately 1.5 tons) covers the 1-ton annual household maize requirement, plus $20-25 \mathrm{~kg} / \mathrm{ha}$ of seeds needed for sowing the next season. In addition, a maize-squash-bean polyculture can produce up to $4 \mathrm{t} / \mathrm{ha}$ of dry matter that can be used as fodder (straw from ten maize plants are used to feed one or two animals per day), or plowed into the soil as green manure, compared with $2 \mathrm{t} / \mathrm{ha}$ in a maize monoculture.

\section{Towards a Radical Re-Design of Agroecosystems}

Studies elucidating the underpinnings of traditional farming systems suggest that in order to incorporate an ecological rationale, modern agroecosystems require systemic change. However, new redesigned farming systems will not emerge from simply implementing a set of practices (rotations, composting, cover cropping, etc.), which tend to address components in isolation, focusing on the optimization of one component (soil fertility, plant nutrition, crop growth, etc.) failing to exploit the properties that emerge through the interaction of the various farm components. Input substitution thus becomes primarily reactive, shifting efforts to solving problems as they arise, ameliorating symptoms rather than discovering root causes [30].

Instead of focusing on one particular component of the agroecosystem, agroecology emphasizes the interrelatedness of all agroecosystem components and the complex dynamics of ecological processes. Thus agroecology is an alternative approach that goes beyond the use of alternative inputs to develop integrated agroecosystems with minimal dependence on external, off-farm inputs. The emphasis is on the design of complex agricultural systems (similar to the rice-fish-duck and milpa systems described above) in which ecological interactions and synergisms between biological components replace inputs to provide the mechanisms for sponsoring soil fertility, productivity, and crop protection [31].

Agroecological system redesign consists in the establishment of an ecological infrastructure that encourages ecological interactions through restoration of agricultural biodiversity at the field and landscape level. As in the case of the rice-fish-duck and milpa systems, well designed biodiverse agroecosystems exhibit a number of synergies which in turn lead to enhanced soil fertility, nutrient cycling and retention, water storage, pest/disease regulation, pollination, and other essential ecosystem services. The production, resource conserving and socio-economic benefits of integrated farms designed based on agroecological principles have been widely described in the literature featuring examples from Latin America, Asia and Africa (Table 1) [32].

The associated cost (labor, resources, and money) to establish the ecological infrastructure of an integrated farm (soil conservation works, living fences, crop rotations, insect habitats, etc.) during the redesign phase tend to be high in the first 3-5 years [33]. Once the rotation and other vegetational designs (cover crops, polycultures, field borders, etc.) start lending ecological services to the farm by setting in motion key ecological processes, the need for external inputs and thus maintenance costs start decreasing as the functional biodiversity of the farm sponsors ecological functions (nutrient cycling, pest regulation, etc.), thus famers do not have to weed or fertilize their fields as often. After years of conversion, the need for external inputs decrease as designed biodiverse farms start sponsoring their own function [30]. The transition is from capital-input intensive to a process-based agriculture (Figure 3). 
Table 1. Main environmental, social and food security impacts of various agroecological initiatives implemented in Latin America [31,33].

\begin{tabular}{l} 
Natural resource conservation: reforested micro-watersheds; forest fragments re-connected; forests remnants enriched \\
with native species \\
Water conservation: harvested-collected water sufficient for family consumption and subsistence crop plots; protection \\
of riparian forests; massive implementation of water harvesting techniques; soil organic matter enrichment to enhance \\
water holding capacity \\
\hline Soil conservation: restoration of degraded soils; erosion control via implementation of several soil conservation \\
practices (terracing, contour farming, mulching, etc.) \\
\hline Recovery and conservation of native germplasm: recovery of thousands of land races and locally adapted seeds via \\
on farm-conservation programs, seed fairs, networks of seed savers and participatory plant breeding projects. \\
\hline Agricultural production: implementation of integrated farms featuring rotations, polycultures and animal integration, \\
producing at least $25 \%$ more per unit land than conventional monoculture farms. More than $70 \%$ of the inputs used in \\
these farms are local, enhancing productive autonomy \\
\hline Food self-sufficiency: At least $60 \%$ of the basic food consumed by the family or community are produced locally \\
\hline Energy self-sufficiency: At least $60 \%$ of the energy required for food production and cooking originates from local \\
sources (biomass, biogas from biodigestors, animal traction, human labor, etc.) \\
\hline Social cohesion: flourishing of local social organizations; collective efforts for restoration and production purposes; \\
empowerment of women and youth; higher social cohesion to resist negative external influences and to fight for rights. \\
\hline Economic viability: local markets; solidarious networks with consumers, low dependency of external inputs; less debt; \\
\hline agroecotourism initiatives controlled by the community; commercialization of products with cultural identity. \\
\hline
\end{tabular}

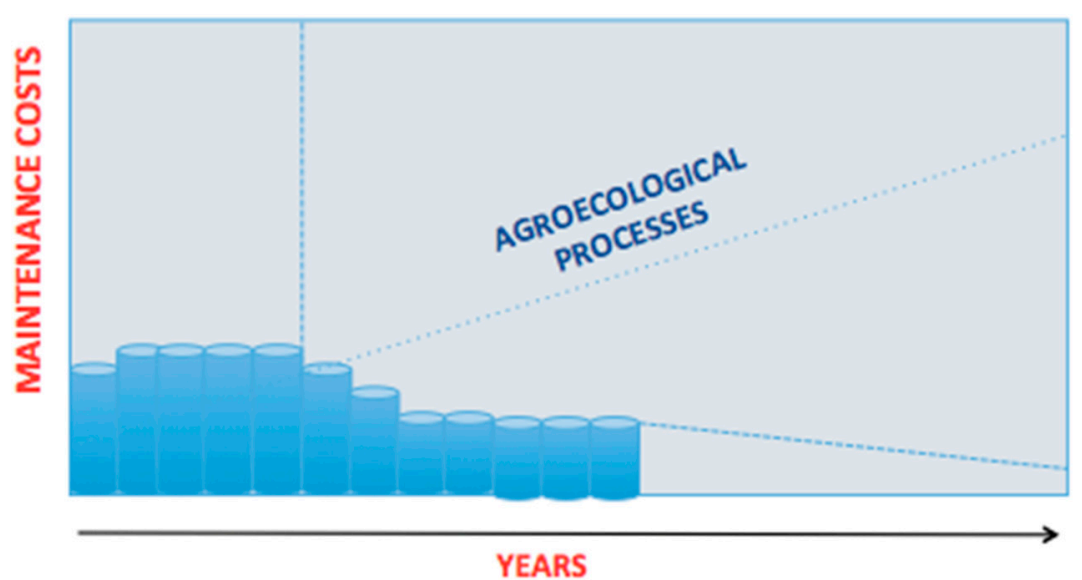

Figure 3. Maintenance costs during the transition towards farming systems redesigned using agroecological principles [30].

\subsection{Redesigning Annual Crop Based Farming Systems}

Larger scale commercial farms are more difficult to transition and initially may require simpler diversification schemes based on 2 or 3 plant species using modern equipment. One such scheme is strip intercropping, which involves the production of more than one crop in strips that are narrow enough for the crops to interact, yet wide enough to permit independent cultivation. Agronomically beneficial strip intercropping systems have usually included corn or sorghum, which readily respond to higher light intensities [34]. Studies with corn and soybean strips 4-12 rows wide demonstrated increased corn yields (5-26 percent higher) and decreased soybean yields (8.5-33 percent lower) as strips got narrower. Alternating corn and alfalfa strips provided greater gross returns than single crops. Strips of $20 \mathrm{ft}$. (approximately 6.1 meters) width were the most advantageous, with substantially higher economic returns than the single crops [35]. This advantage is critical for farmers who have debt-to-asset ratios of 40 percent or higher ( $\$ 40$ of debt for every $\$ 100$ of assets). Such a level has already been reached by more than 11-16 percent of farmers in the mid-western United States who desperately need to cut costs of production by adopting diversification strategies. 
As shown in the Milpa system, legumes intercropped with cereals is a key diversification strategy, not only because of their provision of nitrogen, but also because the mixtures enhance soil cover, smother weeds and increase nutrients (e.g., potassium, calcium and magnesium) in the soil through the addition of biomass and residues to the soil. Such intercropping systems also increase soil microbial diversity such as vesicular arbuscular mycorrhizae (VAM) fungi which facilitate phosphorous transfer to the crops and enhance crops water use efficiency [36]. In the case of adverse weather conditions, such as a delay in the onset of rains and/or failure of rains for a few days, weeks or during the cropping period, an intercropping system provides the advantage that at least one crop will survive to give economic yields, thereby serving as the necessary insurance against unpredictable weather. Polycultures exhibit greater yield stability and lower productivity declines during a drought than monocultures. This was well demonstrated by researchers [37] who examined the effects of drought on polycultures by manipulating water stress on intercrops of sorghum (Sorghum bicolor) and peanut (Arachis spp.), millet (Panicum spp.) and peanut, and sorghum and millet. All the intercrops consistently provided greater yields at five levels of moisture availability, ranging from 297 to $584 \mathrm{~mm}$ of water applied over the cropping season. Interestingly, the rate of over-yielding actually increased with water stress, such that the relative differences in productivity between monocultures and polycultures became more accentuated as stress increased.

No-till row crop production is also promising, given its soil conservation and improvement potential, but it is highly dependent on herbicides. However, there are some organic farmers who practice it without synthetic herbicides. A breakthrough occurred with the discovery that certain winter annual cover crops, notably cereal rye and hairy vetch, can be killed by mowing at a sufficiently late stage in their development and cutting close to the ground. These plants generally do not re-grow significantly, and the clippings form an in situ mulch through which vegetables can be transplanted with no or minimal tillage. The mulch hinders weed seed germination and seedling emergence, often for several weeks. As they decompose, many cover crop residues can release allelopathic compounds that may suppress weed growth [38] by means of phytotoxic substances that are passively liberated through decomposition of plant residues. There are several green manure species that have a phytotoxic effect which is usually sufficient to delay the onset of weed growth until after the crop's minimum weed-free period. This makes post-plant cultivation, herbicides or hand weeding unnecessary, yet exhibits acceptable crop yields [39]. Tomatoes and some late-spring brassica plantings perform especially well, and some large-seeded crops such as maize and beans can be successfully direct-sown into cover crop residues. Not only can cover crops planted in no-till fields fix nitrogen in the short term; they can also reduce soil erosion and mitigate the effects of drought in the long term, as the mulch conserves soil moisture. Cover crops build vertical soil structure as they promote deep macropores in the soil, which allow more water to penetrate during the winter months and thus improve soil water storage.

Experimental results as well as farmers' observations in southern Brazil suggest that cover crops can enhance weed suppression and hence crop productivity possibly through allelopathy and via a host of effects on soil quality and fertility and soil moisture [40]. Results from field trials indicate that the best cover crop mixtures should include a significant proportion of rye, vetch, and fodder radish, as mixtures with these plant species:

- $\quad$ produce large biomass, at least four tons of aboveground dry matter per hectare;

- are readily killed by rolling forming a thick mulch sufficient to provide effective weed control in the subsequent vegetable crop;

- do not suppress the vegetable or grain crop through chemical (allelopathic) or microbial effects (i.e., $\mathrm{N}$ immobilization); and

- increase the proportion of vetch in the mixtures decreases the $\mathrm{C} / \mathrm{N}$ ratio, which gives a gradual release of plant available $\mathrm{N}$. 


\subsection{Redesigning Modern Vineyards}

Cover crops are often planted in between vineyard rows to reduce soil erosion, increase soil fertility, improve soil structure and enhance biological pest suppression. Roots of both grapevines and cover crops form mutualistic symbioses with arbuscular mycorrhizal (AM) fungi, and may be interconnected by AM hyphae. Studies have shown evidence of AM fungi-mediated $15 \mathrm{~N}$ transfer from cover crops to grapevines 5 and 10 days after labeling. $N$ transfer was significantly greater from grass cover crop to the grapevine than from the legume to the grapevine. Possible reasons for the differences between the two cover crops include lower $\mathrm{N}$ enrichment in legume roots, higher biomass of grass roots, and/or differences in AM fungal community composition. Since the fungi can associate with a wide range of plants, certain cover crops can, therefore, be an important reservoir or source of these fungi for young grapevine roots [41].

Because most farmers either mow or plough under cover crops in the late spring, organic vineyards become virtual monocultures without floral diversity in early summer. It is important to maintain a green cover during the entire growing season in order to provide habitat and alternate food for natural enemies of insect pests. An approach to achieve this is to sow summer cover crops that bloom early and throughout the season, thus providing a highly consistent, abundant and well-dispersed alternative food source, as well as microhabitats, for a diverse community of natural enemies [42]. Such food supply decouples predators and parasitoids from a strict dependence on grape herbivores, allowing an early build up of natural enemies in the system, which helps in keeping pest populations at acceptable levels.

Maintaining floral diversity throughout the growing season in northern California vineyards in the form of summer cover crops of buckwheat and sunflower, reduced substantially the abundance of grape leafhoppers and thrips, while the abundance of associated natural enemies increased. In two consecutive years, vineyard systems with flowering cover crops were characterized by lower densities of leafhopper nymphs and adults. Thrips also exhibited reduced densities in vineyards with cover crops in both seasons. During both years, general predator populations on the vines were higher in the cover-cropped sections than in the monocultures. Generally, the populations were low early in the season and increased as prey became more numerous as the season progressed. Dominant predators included spiders, Nabis sp., Orius sp., Geocoris sp., Coccinellidae, and Chrysoperla sp.

The above studies suggest a few guidelines which need to be considered when implementing habitat management strategies to enhance biological pest control in vineyards [43]:

- Select the most appropriate plant species.

- Determine the most beneficial spatial and temporal arrangement of such plants, within and/or around the fields.

- Consider the spatial scale at which the habitat enhancement operates (e.g., field or landscape level).

- Understand the predator-parasitoid behavioral mechanisms influenced by the habitat manipulation.

- Anticipate potential conflicts that may emerge when adding new plants to the agroecosystem.

- Develop ways in which the added plants do not upset other agronomic management practices, and select plants that have multiple effects, such as improving pest regulation, while, at the same time, contributing to soil fertility and weed suppression.

\section{Conclusions}

We have emphasized that merely modifying practices to reduce input use is a step in the right direction but does not necessarily lead to the redesign of a more self sufficient and autonomous farming system. Diversification to break the monoculture is a key agroecological principle to redesign farms. However, diversifying farms per se does not necessarily mean that they are being managed agroecologically, if the collection of crops/animals chosen do not interact biologically to enhance agroecosystem function, as in the case of the Chinese rice-fish-duck systems. Many organic farms are diversified to respond to the variety of market demands, but agroecologically the farms do not work, 
as the crops do not ecologically complement each other therefore farmers still need external inputs (although organic).

Studies of smallholder farming systems in the tropics show that across geographies, biophysical and socio-economic conditions there is a broad range of biodiverse farming systems (intercropping, agroforestry, crop livestock integrated systems, etc.) which sustain a series of ecosystem services such as pest regulation, enhanced productivity (LER), resiliency to climatic extremes, soil health, water conservation, etc. [19]. However, ecosystem services bundles are not sustained by just adding companion species at random, most associations have been tested by farmers for decades if not centuries and farmers maintained them because such systems strike a balance between farm-level productivity, resilience, agroecosystem health and livelihoods [32]. A community of organisms in an agroecosystem becomes more complex when a larger number of different kinds of plants are included, leading to more interactions among arthropods and microorganisms, components of above and below ground food webs. As diversity increases, so do opportunities for coexistence and beneficial interference between species that can enhance agroecosystem sustainability. Diverse systems encourage complex food webs, which entail more potential connections and interactions among members, creating many alternative paths for energy and material flow [25]. For this reason, a more complex community exhibits more stable production and fewer fluctuations in the numbers of undesirable organisms. By enhancing functional biodiversity, a major goal of the redesign process is achieved: strengthening the weak ecological functions in the agroecosystem, allowing farmers to gradually eliminate inputs altogether by relying instead on ecosystem functions [44].

New designs of modern agroecosystems will require systemic change guided by the application of already well defined agroecological principles (Table 2). These principles can be applied by way of various practices and strategies (Table 3), each having different effects on productivity, stability and resiliency within the farm system. One of the key principles is diversification which occurs in many forms at the field (variety mixtures, rotations, polycultures, agroforestry, and crop-livestock integration) and at the landscape level (hedgerows, corridors, etc.), giving farmers a wide variety of options and combinations for the implementation of this strategy. Emergent ecological properties develop in diversified agroecosystems that allow the system to function in ways that maintain soil fertility, crop production, and pest regulation. Most of these systems optimize the application of agroecological principles thus increasing agroecosystem functional diversity as the foundation for soil quality, plant health, crop productivity and system resilience [29].

Table 2. Agroecological principles for the design of biodiverse, energy efficient, resource-conserving and resilient farming systems $[13,14]$.

\begin{tabular}{ll}
\hline 1. & $\begin{array}{l}\text { Enhance the recycling of biomass, with a view to optimizing organic matter decomposition and } \\
\text { nutrient cycling over time. }\end{array}$ \\
\hline 2. & $\begin{array}{l}\text { Strengthen the "immune system" of agricultural systems through enhancement of functional } \\
\text { biodiversity - natural enemies, antagonists, etc., by creating appropriate habitats. }\end{array}$ \\
\hline 3. & $\begin{array}{l}\text { Provide the most favorable soil conditions for plant growth, particularly by managing organic } \\
\text { matter and by enhancing soil biological activity. }\end{array}$ \\
\hline 4. $\quad \begin{array}{l}\text { Minimize losses of energy, water, nutrients and genetic resources by enhancing conservation and } \\
\text { regeneration of soil and water resources and agrobiodiversity. }\end{array}$ \\
\hline 5. $\quad \begin{array}{l}\text { Diversify species and genetic resources in the agroecosystem over time and space at the field and } \\
\text { landscape level. }\end{array}$ \\
\hline 6. $\quad \begin{array}{l}\text { Enhance beneficial biological interactions and synergies among the components of } \\
\text { agrobiodiversity, thereby promoting key ecological processes and services. }\end{array}$ \\
\hline
\end{tabular}


Table 3. Temporal and spatial designs of diversified farming systems and their main agroecological effects [33].

Crop Rotations: Temporal diversity in the form of cereal-legume sequences. Nutrients are conserved and provided from one season to the next, and the life cycles of insect pests, diseases, and weeds are interrupted.

Polycultures: Cropping systems in which two or more crop species are planted within certain spatial proximity result in biological complementarities that improve nutrient use efficiency and pest regulation thus enhancing crop yield stability.

Agroforestry Systems: Trees grown together with annual crops in addition to modifying the microclimate, maintain and improve soil fertility as some trees contribute to nitrogen fixation and nutrient uptake from deep soil horizons while their litter helps replenish soil nutrients, maintain organic matter, and support complex soil food webs.

Cover Crops and Mulching: The use of pure or mixed stands of grass legumes, e.g., under fruit trees can reduce erosion and provide nutrients to the soil and enhance biological control of pests. Flattening cover crop mixtures on the soil surface in conservation farming is a strategy to reduce soil erosion and lower fluctuations in soil moisture and temperature, improve soil quality, and enhance weed suppression resulting in better crop performance.

Crop- livestock mixtures: High biomass output and optimal nutrient recycling can be achieved through cropanimal integration. Animal production that integrates fodder shrubs planted at high densities, intercropped with improved, highly-productive pastures and timber trees all combined in a system that can be directly grazed by livestock enhances total productivity without need of external inputs.

Agroecological management leads to optimal recycling of nutrients and organic matter turnover, closed energy flows, water and soil conservation and balance pest-natural enemy populations, all key processes in maintaining the agroecosystem's productivity and its self-sustaining capacity. The challenge to align modern agricultural systems with ecological principles is immense, especially in the current context of agricultural development where specialization, short-term productivity and economic efficiency are the driving force [45]. This is where the political dimension of agroecology becomes a fundamental complement to the technological thrust.

Acknowledgments: Special thanks to CSFUND from California and the Research Institute for Humanities and Nature (RIHN) from Japan for funding our research over the years.

Author Contributions: This paper is the result of discussions and analysis conducted by the three authors (Miguel A. Altieri, Clara I. Nicholls and Rene Montalba) who equally contributed to the final assemblage of the ideas and concepts contained in this paper.

Conflicts of Interest: The authors declare no conflict of interest.

\section{References}

1. Holt-Gimenez, E.; Altieri, M.A. Agroecology, Food Sovereignty, and the New Green Revolution. Agroecol. Sustain. Food Syst. 2013, 37, 90-102.

2. Rosset, P.M.; Martinez-Torres, M.E. Rural Social Movements and Agroecology: Context, theory and process. Ecol. Soc. 2012, 17, 17-26. [CrossRef]

3. Ponisio, L.C.; Ehrlich, P.R. Diversification, Yield and a New Agricultural Revolution: Problems and Prospects. Sustainability 2016, 8, 1118. [CrossRef]

4. Tomich, T.; Brodt, S.; Ferris, H.; Galt, R.; Horwath, W.; Kebreab, E.; Leveau, J.; Liptzin, D.; Lubell, M.; Merel, P.; et al. Agroecology: A review from a global-change perspective. Annu. Rev. Environ. Resour. 2011, 36, 193-222. [CrossRef]

5. Roland, P.C.; Adamchak, R.W. Tomorrow's Table: Organic Farming, Genetics and the Future of Food; Oxford University Press: Oxford, UK, 2009.

6. Wezel, A.; Bellon, S.; Doré, T.; Francis, C.; Vallod, D.; David, C. Agroecology as a science, a movement, and a practice. Agron. Sustain. Dev. 2009, 4, 503-515. [CrossRef]

7. Lotter, D.W. Organic agriculture. J. Sustain. Agric. 2003, 21, 37-51. [CrossRef]

8. Lampkin, N. Organic Farming; Farming Press: Ipswhich, UK, 2002.

9. Rosset, P.M.; Altieri, M.A. Agroecology versus input substitution: A fundamental contradiction of sustainable agriculture. Soc. Nat. Resour. 1997, 10, 283-295. [CrossRef] 
10. Mc Rae, R.J.; Hill, S.B.; Mehuys, F.R.; Henning, J. Farm scale agronomic and economic conversion from conventional to sustainable agriculture. Adv. Agrono. 1990, 43, 155-198.

11. Guthman, J. Agrarian Dreams. The Paradox of Organic Farming in California; University of California Press: Berkeley, CA, USA, 2014.

12. Gliessman, S.R.; Rosemeyer, M. The Conversion to Sustainable Agriculture: Principles, Processes and Practices; CRC Press: Boca Raton, FL, USA, 2009.

13. Altieri, MA. Agroecology: The Science of Sustainable Agriculture; Westview Press: Boulder, CO, USA, 1995.

14. Gliessman, S.R. Agroecology: The Ecology of Sustainable Food Systems, 2nd ed.; CRC Press: Boca Raton, FL, USA, 2010.

15. Food and Agriculture Organization (FAO). Save and Grow: A Policymaker's Guide to the Sustainable Intensification of Smallholder Crop Production; FAO: Rome, Italy, 2011.

16. Bommarco, R.; Kleijn, D.; Potts, S.G. Ecological intensification: Harnessing ecosystem services for food security. Trends Ecol. Evol. 2013, 28, 230-238. [CrossRef] [PubMed]

17. Denevan, W.M. Prehistoric agricultural methods as models for sustainability. Adv. Plant Pathol. 1995, 11, 21-43.

18. Toledo, V.M.; Barrera-Bassols, N. La Memoria Biocultural: La Importancia Ecológica de las Sabidurías Tradicionales; ICARIA Editorial: Barcelona, Spain, 2009.

19. Ewel, J.J. Designing agricultural ecosystems for the humid tropics. Annu. Rev. Ecol. Syst. 1986, 17, $245-271$. [CrossRef]

20. Koohafkan, P.; Altieri, M.A. Forgotten Agricultural Heritage: Reconnecting Food Systems and Sustainable Development; Earthscan Food and Agriculture Series; Routeledge: London, UK, 2016.

21. Zheng, Y.; Deng, G. Benefits analysis and comprehensive evaluation of rice -fish-duck symbiotic model. Chin. J. Eco-Agric. 1998, 6, 48-51.

22. Lu, J.; LI, X. Review of rice-fish-farming systems in China-One of the Globally Important Ingenious Agricultural Heritage Systems (GIAHS). Aquaculture 2006, 260, 106-113. [CrossRef]

23. Francis, C.A. Multiple Cropping Systems; MacMillan: New York, NY, USA, 1986.

24. Kass, D.C.L. Polyculture Cropping Systems: Review and Analysis; New York State College of Agriculture and Life Sciences, Cornell University: Ithaca, NY, USA, 1978; Volume 32.

25. Lithourgidis, A.S.; Dordas, C.A.; Damalas, C.A.; Vlachostergios, D.N. Annual Intercrops: An Alternative Pathway for Sustainable Agriculture. Aust. J. Crop Sci. 2011, 5, 396-410.

26. Altieri, M.A.; Nicholls, C.I. Biodiversity and Pest Management in Agroecosystems, 2nd ed.; The Harworth Press: Binghamton, NY, USA, 2004.

27. Vandermeer, J. The Ecology of Intercropping; Cambridge University Press: Cambridge, UK, 1989.

28. Malezieux, E. Designing cropping systems from nature. Agron. Sustain. Dev. 2012, 32, 15-29. [CrossRef]

29. Altieri, M.A.; Trujillo, J. The agroecology of corn production in Tlaxcala, Mexico. Hum. Ecol. 1987, 15, 190-220. [CrossRef]

30. Nicholls, C.I.; Altieri, M.A.; Vazquez, L. Agroecology: Principles for the Conversion and Redesign of Farming Systems. J. Ecosyst. Ecography 2016, S5. [CrossRef]

31. Altieri, M.A. Agroecology: The science of natural resource management for poor farmers in marginal environments. Agric. Ecosyst. Environ. 2002, 93, 1-24. [CrossRef]

32. IPES-Food. From Uniformity to Diversity: A Paradigm Shift from Industrial Agriculture to Diversified Agroecological Systems. International Panel of Experts on Sustainable Food Systems. Available online: www.ipes-food.org (accessed on 12 September 2016).

33. Altieri, M.A.; Nicholls, C.I. Agroecology: Scaling up for food sovereignty and resiliency. In Sustainable Agriculture Reviews; Springer: Dordrecht, The Netherlands, 2012; Volume 11.

34. Francis, C.A.; Jones, C.; Crookston, A.; Wittler, K.; Goodman, S. Strip cropping corn and grain legumes: A review. Am. J. Altern. Agric. 1986, 1, 159-164.

35. West, T.D.; Griffith, D.R. Effect of strip intercropping corn and soybean on yield and profit. J. Prod. Agric. 1992, 5, 107-110. [CrossRef]

36. Machado, S. Does intercropping have a role in modern agriculture? J. Soil Water Conserv. 2009, 64, 55A-57A. [CrossRef]

37. Natarajan, M.; Willey, R.W. The effects of water stress on yield advantages of intercropping systems. Field Crops Res. 1986, 13, 117-131. [CrossRef] 
38. Moyer, J. Organic No-Till Farming; Rodale Press: Emmaus, PA, USA, 2010.

39. Liebman, M.; Mohler, C.L.; Staver, C.P. Ecological Management of Agricultural Weeds; Cambridge University Press: Cambridge, UK, 2001.

40. Altieri, M.A.; Lana, M.A.; Bittencourt, H.; Kieling, A.S.; Comin, J.J.; Lovato, P.E. Enhancing crop productivity via weed suppression in organic no-till cropping systems in Santa Catarina, Brasil. J. Sustain. Agric. 2011, 35, 1-15. [CrossRef]

41. Cheng, X.; Baumgartner, K. Arbuscular mycorrhizal fungi-mediated nitrogen transfer from vineyard cover crops to grapevines. Biol. Fertil. Soils 2004, 40, 406-412. [CrossRef]

42. Nicholls, C.I.; Parrella, M.P.; Altieri, M.A. Reducing the abundance of leafhoppers and thrips in a norrthern California organic vineyard through maintenance of full season floral diversity with summer cover crops. Agric. For. Entomol. 2000, 2, 107-113. [CrossRef]

43. Altieri, M.A.; Ponti, L.; Nicholls, C.I. Manipulating biodiversity for improved pest management: Case studies from Northern California. Int. J. Biodivers. Sci. Manag. 2005, 1, 191-203. [CrossRef]

44. Altieri, M.A.; Nicholls, C.I.; Henao, A.; Lana, M.A. Agroecology and the design of climate change-resilient farming systems. Agron. Sustain. Dev. 2015, 35, 869-890. [CrossRef]

45. Phelan, P.L. Ecology-based agriculture and the next green revolution: Is modern agriculture exempt from the laws of ecology? In Sustainable Agroecosystem Management: Integrating Ecology, Economics, and Society; Bohlen, P.J., House, G., Eds.; CRC Press: Boca Raton, FL, USA, 2009; pp. 97-135.

(c) 2017 by the authors. Licensee MDPI, Basel, Switzerland. This article is an open access article distributed under the terms and conditions of the Creative Commons Attribution (CC BY) license (http:/ / creativecommons.org/licenses/by/4.0/). 